\title{
EXPLORING THE RELATIONSHIPS AMONG THE ANTECEDENTS OF BRAND LOYALTY: A RESEARCH ON AN APPAREL BRAND
}

\author{
Çağatan Taşkın ${ }^{1 *}$, Gül Gökay Emel ${ }^{2}$, Ahmet Akif Karadamar ${ }^{3}$, Nagihan Memiş ${ }^{4}$ \\ ${ }^{1}$ Assoc. Prof. Dr., Uludağ University, TURKEY, ctaskin@uludag.edu.tr \\ ${ }^{2}$ Asst. Prof. Dr., Uludağ University, TURKEY, ggokay@uludag.edu.tr \\ ${ }^{3}$ Res. Asst., Uludağ University, TURKEY, aakaradamar@uludag.edu.tr \\ ${ }^{4}$ Res. Asst., Uludağ University, TURKEY, nagihanmemis@uludag.edu.tr \\ ${ }^{*}$ Corresponding author
}

\begin{abstract}
There is a severe competition in apparel industry both in the world and Turkey. With the consumers' increasing needs, wants and the change of their needs from functional to symbolic benefits, clothing style has become an important way of expressing personal identity. Thus, companies which are operating in the apparel industry are being forced to imply efficient marketing strategies and to increase the loyalty of their customers for their brands. Brand loyalty generates numerous benefits like erecting barriers to competitors, generating greater sales and revenues, reducing customer acquisition costs, and inhibiting customers' susceptibility to marketing efforts of competitors. Because of these reasons, it has been used by companies as a strategic tool to obtain sustainable competitive advantages in markets. It is also argued in the extant literature that a critical issue for the continued success of a firm is its capability to retain its current customers and make them loyal to its brands. Understanding how those factors affect brand loyalty will help companies in gaining competitive advantages.

The aim of this study is to explore the relationships among the antecedents of brand loyalty on an apparel brand that is very popular among university students. Brand communication, brand image, brand trust are taken as the antecedents of brand loyalty in the research model. Main sample of the research consists of university students in Bursa. Hypotheses are tested with the help of structural equation modelling. This study is expected to make academic and practical contributions to the existing branding literature and the companies in apparel industry, Turkey in particular.
\end{abstract}

Keywords: Brand Loyalty, Apparel Brand, Brand Communication, Brand Image, Brand Trust, Structural Equation Modelling, Bursa.

\section{INTRODUCTION}

In today's consumer-oriented markets, companies need sustainable marketing strategies in order to gain competitive advantages. Companies in apparel industry should give more importance to consumers because the reason of brand purchase decisions has shifted from functional to symbolic benefits. This reality leads to a more severe competition in the sector. The key marketing strategy to struggle with competition is creating brand loyalty. Brand loyalty generates numerous benefits like erecting barriers to competitors, generating 
greater sales and revenues, reducing customer acquisition costs, and inhibiting customers' susceptibility to marketing efforts of competitors. Thus, having information about the antecedents of brand loyalty will help companies to imply more efficient marketing strategies.

Companies in apparel industries also give importance to university students because they often use branded apparel products and tend to share their experiences about brands. That's why, university students generates an important market segment. The aim of this study is to explore the relationships among the antecedents of brand loyalty on an apparel brand that is very popular among university students. Brand communication, brand image, brand trust are taken as the antecedents of the brand loyalty in the research model. Main sample of the research consists of university students in Bursa. Hypotheses are tested with the help of structural equation modelling. This study is expected to make academic and practical contributions to the existing branding literature and the companies in apparel industry, Turkey in particular.

\subsection{Antecedents of Brand Loyalty}

\subsubsection{Brand Communication}

Brand communication which was found to have an important role in building positive brand attitudes (Anisimova and Sultan, 2014, pp. 514) is the main integrative component in managing brand relationships with customers (Şahin et al., 2012, pp.1362). Brand communication also curtails the process of customer's brand decision making and makes a habit of that choice (Schivinski and Dabrowski, 2014, pp. 36). The audience is exposed to a brand in brand communication, thereby customer response is affected. When searching to satisfy customers and creating positive brand attitude, in the long run, the effect of brand communications must be examined closely (Grace and O'Cass, 2005, pp. 107). Its effect can be determined by analyzing brand recall and brand awareness alongside strength, uniqueness and favorability of brand associations in consumer memory. Brand communication can also be one-way and two-way direction (Zehir et al., 2011, pp. 1219; Şahin et al., 2012, pp.1362).

\subsubsection{Brand Image}

Brand image is crucial in an organization in terms of ability to form attitudes of consumers toward the brand, product and service and to influence their behavioral components towards the organization (Michaelidou et al., 2015, pp. 1657). Notwithstanding, there is less agreement of conceptualization of brand image, it can be defined as "perceptions about the brand as reflected by the brand associations held in consumer memory" (Keller, 2003, pp. 3). Brand associations are the linkages between the brand and brand beliefs or perceptions in consumer's memory and embody the trusts about a brand's attributes and benefit from utilizing it (Sang et al.,2015, pp. 391). High brand image indicates that consumer has a perception in a certain level of product quality, thus brand image plays an important role in purchasing decision-making $\mathrm{(Wu}$, 2015, pp. 238).

\subsubsection{Brand Trust}

Brand trust is defined as "feeling of security held by the consumer in his/her interaction with the brand, that it is based on the perceptions that the brand is reliable and responsible for the interests and welfare of the consumer". In this definition, brand trust includes willingness to put oneself at risk, feelings of confidence and security, common anticipation and to make reliable to the brand (Elena et al., 2003, pp. 11). According to Chaudhuri and Holdbrook (2001), brand trust is defined as "the willingness of the average consumer to rely on the ability of the brand to perform its stated function", while in paper of Xingyuan et al. (2010), "brand trust is a consumer's disposition toward a brand characterized by positive expectations and willingness to rely on the brand". Brand trust contains knowledge or cognition based components and emotional or affect based components (Srivastava et al., 2015, pp. 330).

\subsubsection{Brand Loyalty}

The concept of brand loyalty is defined as the individual's positive attitude that is repeated over a period towards the product of a brand (Baig et al., 2015, pp. 01). Brand loyalty has been considered as both behavioral and attitudinal dimension in its conceptual development process. Behavioral dimension refers to outcome of repeat purchase behavior and attitudinal dimension refers to consequence of multi-dimensional cognitive attitudes towards a specific brand (Audi et al., 2015, pp. 279; Baig et al., 2015, pp. 03; Zhang et al., 2015 , pp. 15). The origins of brand loyalty are one of the main concerns for brand management because it enhances long term financial performance of firms and shows the long term relationship between consumers and brands (Brexendorf et al, 2009, pp. 1148; Jones and Sasser, 1995, pp. 11; Chaudhuri and Holbrook, 2001, pp. 82). 


\subsection{Literature Review}

In creating of the customer's brand loyalty, the organization must give importance to brand image (Momen et al., 2015, pp. 36). Rahi (2015) stated that brand image is an important key for brand loyalty in banking sector. In that paper, the study covered brand image as a moderator between customer loyalty and internet banking. Fatema et al. (2013) shows that there is a relation between brand image and brand loyalty. In their paper of Seric et al. (2014), it is demonstrated that brand image has a strong effect on the development of brand loyalty in hospitality industry. In He and Lai's paper (2014), the relationship between brand image and brand loyalty is considered with two categories of brand image: symbolic and functional images. Findings of the study show that brand image has a mediating role between brand loyalty and corporate social responsibility (He and Lai, 2014, pp. 260). Nazari et al. (2015) show that green brand image influences brand loyalty indirectly and positively. In Alhaddad (2015)'s study, a brand loyalty model is developed. The findings of the study show that brand image which is a dimension of brand loyalty has a significant positive effect on brand loyalty. In another paper which investigated the relationship between brand image and brand loyalty (Nyadzayo and Khajehzadeh, 2016, pp. 268), it is implied that when the brand image is favorable, the firm's efforts to managing service quality, customer satisfaction, customer value, as well as CRM practices have higher congruence with customer loyalty. In Chung et al. (2016)'s study, the findings show that brand image is a very important factor in enhancing customer loyalty of low-price cosmetic brands.

Brand trust builds a highly valued lasting relationship between the brand and the consumer, and is one of the important determinants of brand loyalty (Bianchi et al., 2014, pp. 95; Morgan and Hunt, 1994, pp. 20-38). In Laroche et al. (2012)'s study, the relationship between brand trust and brand loyalty is investigated in the context of enhanced relationships in brand community. The findings show that brand trust has a fully mediating role in converting the effects of relevant relationships (Laroche et al., 2012, pp. 76). In Erciş et al. (2012)'s study, it is suggested that enterprises should attach more importance to creating trust in consumer loyalty. In So et al. (2014)'s paper, it is showed that customer engagement has an effect on brand trust and hence brand loyalty in hospitality sector. In that paper, it is stated that brand trust is a significant predictor of service brand loyalty. In Nikhashemi et al. (2015)'s study, brand trust is considered to identify the significance of customer brand identification towards building customer brand loyalty as a mediator. In their study, it is found that brand trust fully mediates that relationship (Nikhashemi et al., 2015, pp. 182). In Lee et al. (2015)'s study, the effects of usability in brand loyalty is covered indirectly through the mediators of brand satisfaction and brand trust. In Chung et al. (2015)'s study, the importance of sub-dimensions of perceived value and brand loyalty is investigated. The findings of the study support that there is a positive linkage between brand trust and brand loyalty (Chung et al., 2015, pp. 10). In Veloutsou's (2015) study, brand trust is found to be an antecedent of brand loyalty in an indirect manner. In Liao's study (2015), the mediating effect of brand trust on brand loyalty and brand equity is examined. In the study, three antecedents which are cognitive and experiential factors are evaluated to identify effects. The results of the study show that brand trust has a mediator role in bridging the influences of these antecedents on brand loyalty and brand equity (Liao, 2015, pp. 603). In Bilgihan (2016)'s paper, the effect of brand trust on brand loyalty is investigated in e-commerce. The findings of the study show that trust is a crucial element for long-term business relationship in online context (Bilgihan, 2016, pp. 110).

Marketers seek to create and maintain positive attitudes towards brands. These positive attitudes such as brand trust and loyalty are crucial for long-term success. Marketers use tools for maintaining brand loyalty. Brand loyalty can be enhanced with the marketing communication which is one of the relevant tools (Hoek et al., 2000, pp.415; Orzam et al., 2016, pp. 142). In the extant literature, Schivinski and Dabrowski (2014) investigated the effect of firm-created and user-generated brand communication on brand loyalty. The findings of their study show that user generated social media brand communication has a positive effect on brand loyalty (Schivinski and Dabrowski, 2015, pp. 31). In Cai et al. (2014)'s study, the effects of intergenerational (IG) communication on brand equity are investigated. The findings show that there is linkage indirectly between IG perceived quality and IG brand loyalty. In Virvilaite et al. (2015)'s study, the correlation between word of mouth which is examined by academic researchers in the topic of brand communication (Schivinski and Dabrowski , 2015, pp. 34) and brand loyalty is found as positive (Virvilaite et al., 2015, pp. 645). In another study which analyzes the correlation between word of mouth communication and brand loyalty (Nikhashemi et al., 2015), brand loyalty is considered as an outcome in generating word of mouth communication. In Orzan et al. (2016)'s study, research's starting point is that social media communication influences costumer's trust, effect and loyalty towards brand. The findings of the study point out that social media marketing communications are related to brand trust and brand effect which are determinants of brand loyalty. 


\section{RESEARCH METHODOLOGY}

\subsection{Conceptual Model and Research Hypotheses}

In this section, the conceptual model that examines the antecedents of brand loyalty on apparel brand is presented. Brand communication, brand image and brand trust were selected as possible determinants of the brand loyalty for the research. The conceptual model of the study is shown in Figure 1. In this conceptual model; "Communic", "Image", "Trust" and "Loyalty" variables represent brand communication, brand image, brand trust and brand loyalty respectively.

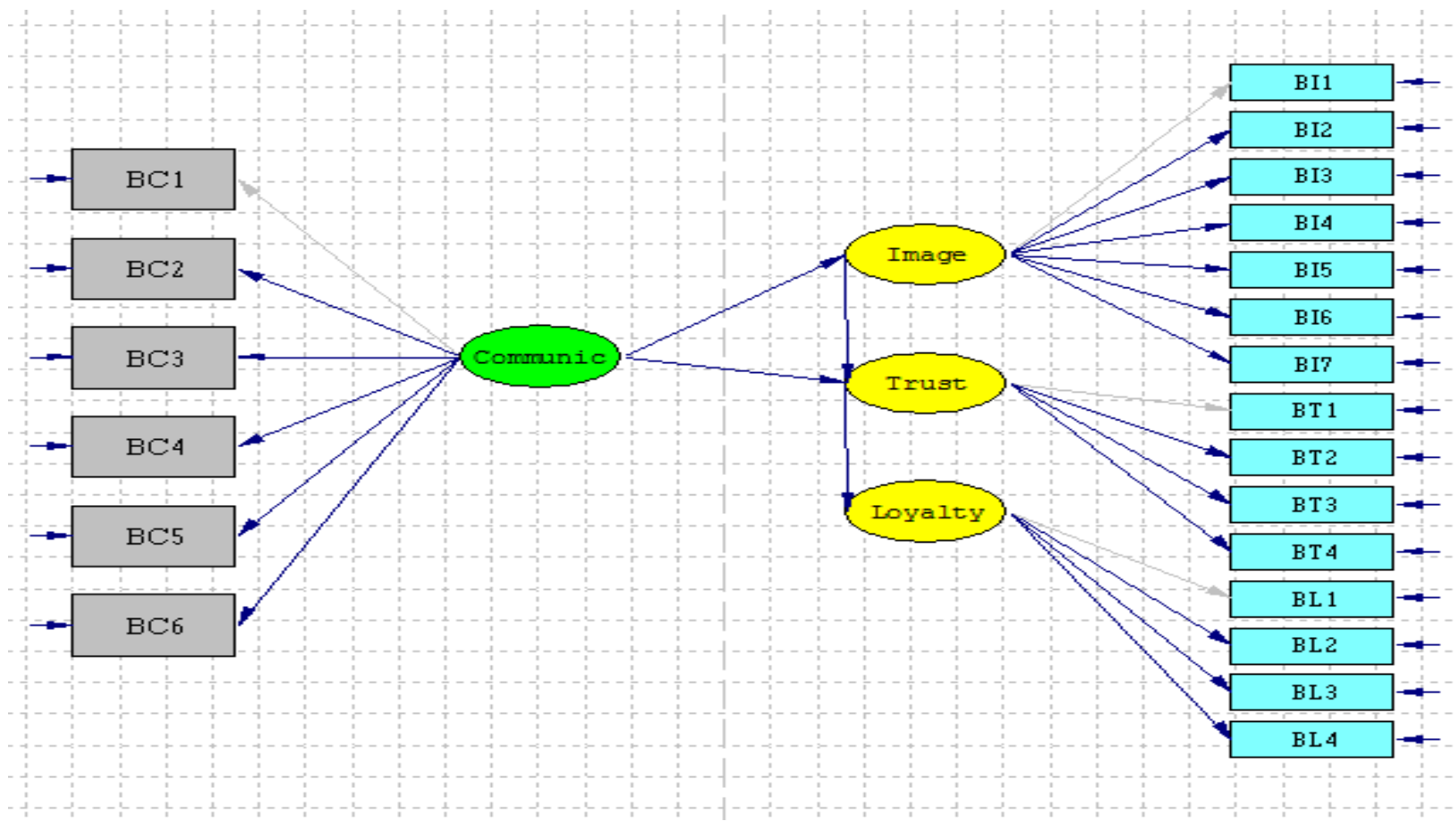

Figure 1: Conceptual Model

As seen from Figure 1, research hypotheses are:

$\mathrm{H}_{1}$ : Brand communication has a positive effect on brand image.

$\mathrm{H}_{2}$ : Brand communication has a positive effect on brand trust.

$\mathrm{H}_{3}$ : Brand image has a positive effect on brand trust.

$\mathrm{H}_{4}$ : Brand trust has a positive effect on brand loyalty.

A structured questionnaire was used in the research. Main sample of the research consists of university students in Bursa. After collecting data, the reliability of the scale was measured by Cronbach's Alpha. Then, an exploratory factor analysis has been executed. After providing the necessary conditions, structural equation modeling has been applied to test the conceptual model of the research.

The scales used in the research are shown with their references in Table 1 below.

Table 1: Scales Used in the Research

\begin{tabular}{|l|l|}
\hline Variables & References \\
\hline Brand Communication & Grace and O'Case, 2005; Zehir et al., 2011; Chinomona, 2016. \\
\hline Brand Image & Salinas and Pérez, 2009; \\
\hline Brand Trust & $\begin{array}{l}\text { Chaudhuri and Holbrook, 2001; Hsteh and Hiang 2004; Dixon et al. } \\
\text { 2005; Zehir et al., 2011; Chinomona, 2016. }\end{array}$ \\
\hline Brand Loyalty & $\begin{array}{l}\text { Chaudhuri and Holbrook, 2001; Algesheimer, Uptal and Herrmann, } \\
\text { 2005; Hohenstein, et al. 2007 }\end{array}$ \\
\hline
\end{tabular}




\subsection{Findings}

\subsubsection{Reliability Analysis}

A scale used in social sciences is generally tested by Cronbach's Alpha. The data gathered has been transferred into the IBM SPSS 22 program. Cronbach's Alpha values are; 0,87, 0,88, 0,88, 0,79 and 0,93 for brand communication, brand image, brand trust, brand loyalty and the whole scale respectively.

\subsubsection{Exploratory Factor Analysis}

In Table 2, results of KMO and Bartlett's tests can be seen. Rotated component matrix results indicate that four factors are formed as in the conceptual model.

Table 2: KMO and Bartlett's Test

\begin{tabular}{|l|l|r|}
\hline \multicolumn{2}{|c|}{ Kaiser-Meyer-Olkin Measure of Sampling Adequacy. } &, 867 \\
\hline & Approx. Chi-Square & 1568,058 \\
\hline $\begin{array}{l}\text { Bartlett's Test } \\
\text { of Sphericity }\end{array}$ & df & 210 \\
\hline & Sig. &, 000 \\
\hline
\end{tabular}

Table 3: Rotated Component Matrix ${ }^{a}$

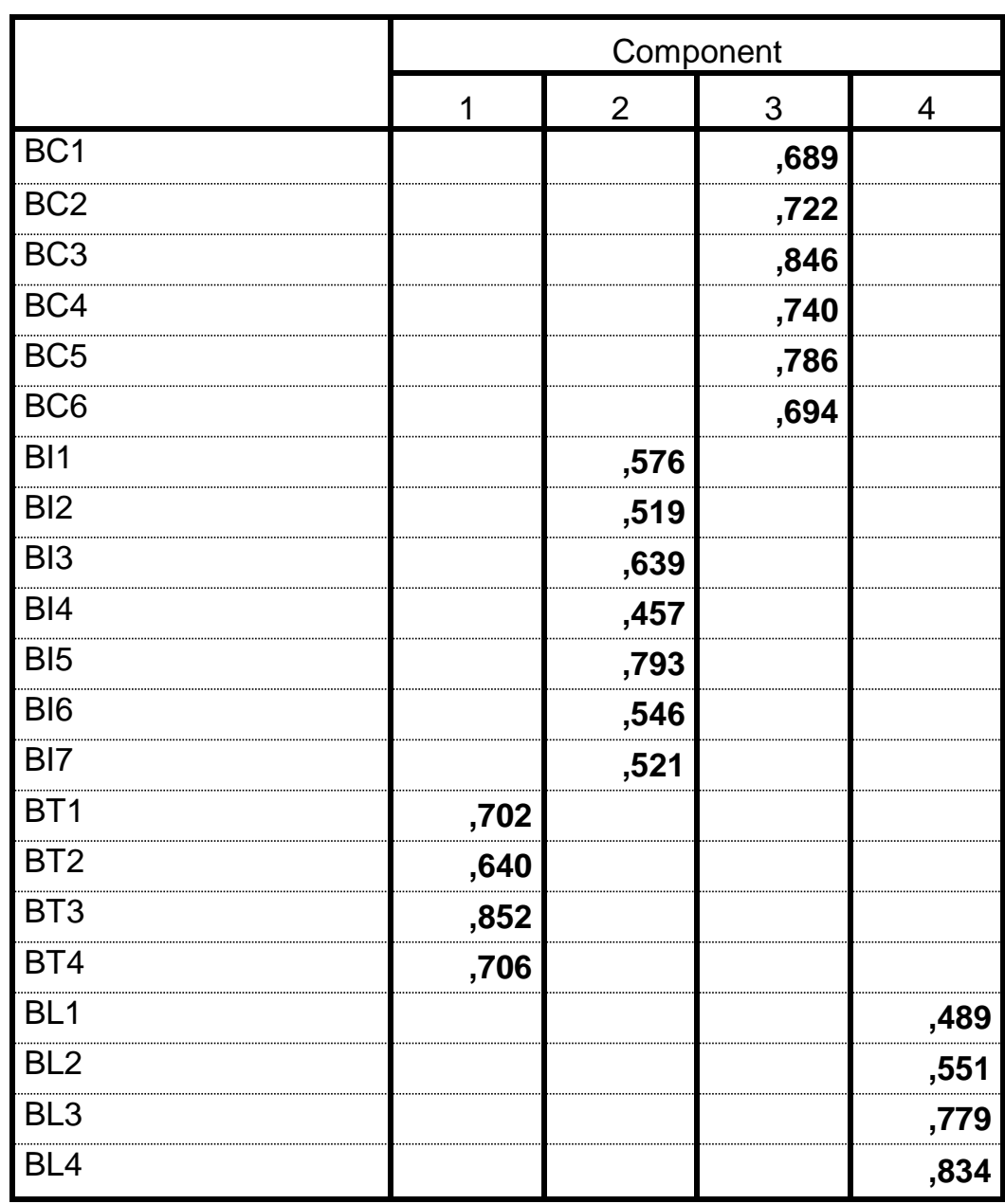

Extraction Method: Principal Component Analysis.

Rotation Method: Varimax with Kaiser Normalization.

a. Rotation converged in 11 iterations. 


\subsubsection{Hypothesis Testing and Structural Model}

In this section, the results of the structural model are given. The reliability of the structural model can be measured by various statistics. These are called goodness of fit statistics generally. Common used fit statistics are shown in Table 4. Goodness of fit statistics indicates that the structural model is valid.

Table 4: Goodness of Fit Statistics

\begin{tabular}{|l|c|}
\hline The Goodness of Fit Statistics & Value \\
\hline Chi Square/Degrees of Freedom & 2,20 \\
\hline GFI & 0,89 \\
\hline AGFI & 0,87 \\
\hline NFI & 0,90 \\
\hline CFI & 0,94 \\
\hline IFI & 0,94 \\
\hline RMSEA & 0,10 \\
\hline RMR & 0,06 \\
\hline Standardized RMR & 0,09 \\
\hline
\end{tabular}

The GFI, AGFI, NFI, CFI and IFI are widely used statistical tests and provide evidence for goodness of fit and hypothesized model. They are 0,89, 0,87, 0,90, 0,94 and 0,94 respectively. These values show that the structural model has good values. The RMSEA, RMR and SRMR values also show that the model has a good fit.

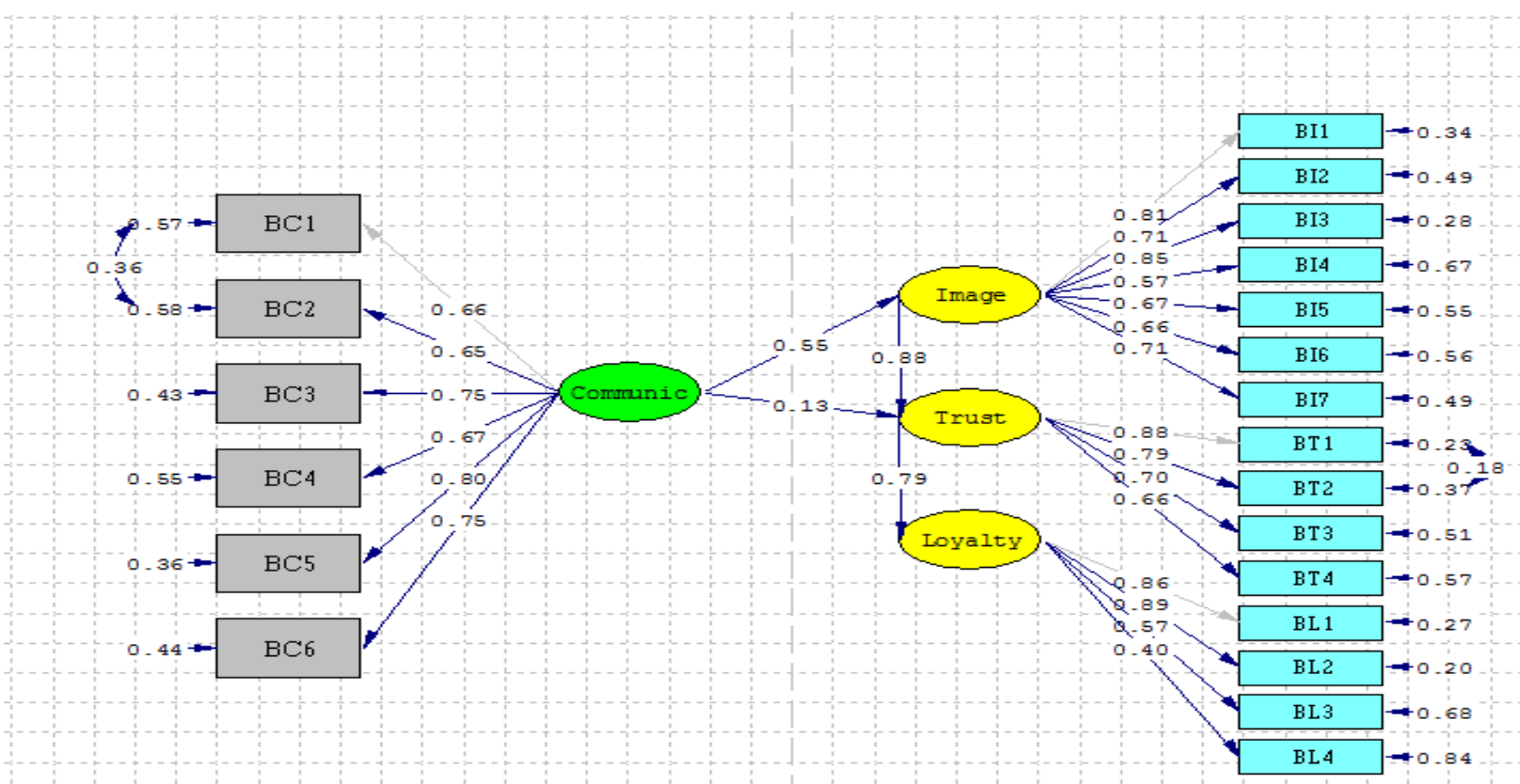

Figure 2. Structural Model and Standardized Path Coefficients

The structural model with the standardized path coefficients is shown in Figure 2. As can be seen in Figure 2 brand trust has a direct and positive effect on brand loyalty. Brand image has a positive and direct effect on brand trust and brand communication has a positive and direct effect on brand image while the effect of brand communication on brand trust was found to be statistically insignificant. The results of hypothesis, the paths of the model and the path coefficients are given in the Table 5.

Table 5: Results of Structural Equation Model Analysis

\begin{tabular}{|l|l|l|l|}
\hline Paths & Hypothesis & Path Coefficients & Result \\
\hline $\begin{array}{l}\text { Brand Communication- Brand } \\
\text { Image }\end{array}$ & $\mathrm{H} 1$ & 0,55 & Accepted \\
\hline Brand Communication-Brand Trust & $\mathrm{H} 2$ & 0,13 & Rejected \\
\hline Brand Image-Brand Trust & $\mathrm{H} 3$ & 0,88 & Accepted \\
\hline Brand Trust- Brand Loyalty & $\mathrm{H} 4$ & 0,79 & Accepted \\
\hline
\end{tabular}


The path coefficients between "brand communication" and "brand image", "brand image" and "brand trust" and "brand trust" and "brand loyalty" are 0,55, 0,88 and 0,79 respectively. It shows that brand communication and brand image have effects on the brand loyalty with the mediating affect of brand trust and brand trust has a positive and direct effect on brand loyalty.

\section{DISCUSSION AND IMPLICATIONS}

This research contributes to literature by exploring the relationships between brand communication, brand image, brand trust and brand loyalty for an apparel brand which is popular among university students. According to many researchers (Chaudhuri and Holbrook, 2001; Delgado-Ballester and Luis MunueraAlemán, 2001) brand trust is a key determinant of brand loyalty. Chaudhuri and Holbrook (2001) emphasized that brand trust is positively related to two different types of brand loyalty -purchase and attitudinal loyalty. In apparel sector there are several brands and these brands try to increase brand loyalty through their brand. Because of this competitive environment consumers have too many choices to buy apparel product. If apparel brands want to be purchased by consumers, marketing managers have to develop strategies to enhance consumers' trust to their brand. Lau and Lee (1999) confirmed that if one side trusts other side, consumer trust in a brand will lead to consumer loyalty to that brand.

Orzan et al. (2016) investigated the relationships between brand trust, brand affect and brand loyalty. In their study they found that brand trust has a direct effect on brand loyalty and influences brand loyalty with the brand affect's mediating role. Harris and Goode (2004) tested Oliver's four-dimension scale of loyalty - trust, satisfaction, value and service quality. The results of that study show that trust is significantly linked to loyalty and is a key driver of customer loyalty. Kim, Chung and Lee (2011) found that brand trust plays a key role as an antecedent of customer loyalty in online shopping for tourism products and services.

Similar to previous findings, brand trust was found to have an effect on brand loyalty directly in this study. These results show that consumers want to reduce their risk through trusted brands. There are many products and brands in apparel industry. Consumers want to be pleased with their choices. Thus they tend to buy brands which they trust.

There are few studies about investigating the effect of brand communication on brand image. Kavaratzis (2004) who developed place brand communication model (Braun, Eshuis and Klij, 2014, p. 65) says that image includes three type of communication, namely primary, secondary and tertiary (Kavaratzis, 2004, p. 67). In Braun, Eshuis and Klij's (2014) study they hypothesized traditional place brand communication, WOM place brand communication and physical place brand communication have positive impacts on place brand image. In the result of their study they found that WOM place brand communication and physical place brand communication have significant effects on place brand image but traditional place brand communication has no effect. According to the findings of the current study, brand communication has a positive effect on brand image like Braun, Eshuis and Klij's study. More researches should be done in order to validate these results.

According to previous studies (Ball, Simões Coelho, and Machás, 2004; Zehir et al., 2011), researchers found that brand communication has a positive effect on brand trust. In this study, the impact of brand communication on brand trust was not found. Brand communication helps consumers to create an attitude to the brand. This attitude can be positive or negative, and influence young consumers' purchase intention. Kim et al. (2009)'s study suggested that purchase intention of young consumers is related with brand's perceived value, prestigious image and consumers' emotional value.

Hoq, Sultana and Amin (2010) aim to analyze the role of consumer trust, satisfaction and image's effects on Malaysian Islamic bank consumers' loyalty. The results of their study demonstrate that the relationship between brand image and brand trust is positive and brand trust has a mediator role between brand image and brand loyalty. Nazari, Ghasemi and Saeidi (2015) revised and developed a model tested by Chen (2010). According to their results brand image is directly related with brand trust and influences brand loyalty with mediating effect of brand trust. Similar results have been found by Schlesinger, Cervera and PérezCabañero (2016). They explored the roles of four variables -brand image, trust, satisfaction and shared values, direct and indirect description of alumni loyalty. Their results show that brand image has a positive effect on brand trust and affects brand loyalty by brand trust's mediating role. Similar to these studies Ball, Simões Coelho, and Machás, (2004) and Alhaddad (2015) found direct effect of brand image on brand trust. But they also found direct and indirect effect of brand image on brand loyalty.

In this study, brand image is found to have an effect on brand loyalty through the brand trust. As mentioned above, in some studies brand image has indirect effect but in other studies it has both direct and indirect effects. These results show that brand image is an important antecedent of both brand trust and brand loyalty. 
According to the modelling results, brand image and brand trust have been found to be vital antecedents in forming brand loyalty. Thus, companies should focus on marketing strategies that most lead to positive brand image and powerful brand trust. Another important result is that brand communication antecedent has a direct and strong impact on brand image. So, apparel firms should generate efficient marketing communication strategies.

\section{REFERENCE LIST}

Algesheimer, R., Dholakia, U. M. and Herrmann, A. (2005). The social influence of brand community: Evidence from European car clubs. Journal of marketing. vol. 69(3)

Alhaddad, A. (2015). Perceived quality, brand image and brand trust as determinants of brand loyalty. Journal of Research in Business and Management. vol. 3(4)

Anisimova, T. and Sultan, P. (2014). The role of brand communications in consumer purchases of organic foods: a research framework. Journal of Food Products Marketing, vol. 20(5).

Audi, M., Al Masri, R. and Ghazzawi, K. (2015). The effect of celebrity endorsement on creating brand loyalty: an application on the lebanese cosmetic sector's demand. International Journal of Business Management and Economic Research. vol. 6(5).

Baig, S. A., Zia-Ur-Rehman, M., Saud, E. J., Aslam, T. and Shafique, A. (2015). Mediating roles of customer satisfaction and customer trust in building brand loyalty. An empirical study in Pakistan. Business Management Dynamics. vol. 4(10).

Ball, D., Simões Coelho, P., and Machás, A. (2004). The role of communication and trust in explaining customer loyalty: An extension to the ECSI model. European journal of marketing, vol. 38(9/10).

Bianchi, C., Drennan, J., and Proud, B. (2014). Antecedents of consumer brand loyalty in the Australian wine industry. Journal of Wine Research. vol. 25(2)

Bilgihan, A. (2016). Gen Y customer loyalty in online shopping: An integrated model of trust, user experience and branding. Computers in Human Behavior. vol. 61.

Braun, E., Eshuis, J., and Klijn, E. H. (2014). The effectiveness of place brand communication. Cities, vol. 41.

Brexendorf, T. O., Mühlmeier, S., Tomczak, T. and Eisend, M. (2010). The impact of sales encounters on brand loyalty. Journal of Business Research. vol. 63(11)

Cai, Y., Zhao, G. and He, J. (2015). Influences of two modes of intergenerational communication on brand equity. Journal of Business Research. vol. 68(3).

Chaudhuri, A. and Holbrook, M. B. (2001). The chain of effects from brand trust and brand affect to brand performance: the role of brand loyalty. Journal of Marketing. vol. 65(2).

Chen, Y. S. (2010). The drivers of green brand equity: Green brand image, green satisfaction, and green trust. Journal of Business Ethics, vol. 93(2).

Chinomona R. (2016). Brand communication, brand image and brand trust as antecedents of brand loyalty in Gauteng province of South Africa. African Journal of Economic and Management Studies. vol. 7(1).

Chung, K. H., Yu, J. E., Kim, W. and Shin, J. I. (2016). The antecedent and consequences of brand image in a low-priced cosmetic brand of South Korea: The moderating effect of gender. International Journal of u- and e- Service Science and Technology. vol. 9(2).

Chung, K., Oh, J., Kim, W. and Park, G. (2015). The effects of perceived value of mobile phones on user satisfaction, brand trust, and loyalty. Advanced Science and Technology Letters. vol. 114.

Delgado-Ballester, E., and Luis Munuera-Alemán, J. (2001). Brand trust in the context of consumer loyalty. European Journal of marketing, vol. 35(11/12)

Delgado-Ballester, E., Munuera-Aleman, J. L. and Yague-Guillen, M. J. (2003). Development and validation of a brand trust scale. International Journal of Market Research. vol. 45(1) 
Dixon, J., Bridson, K., Evans, J., and Morrison, M. (2005). An alternative perspective on relationships, loyalty and future store choice. The International Review of Retail, Distribution and Consumer Research, vol. 15(4).

Erciş, A., Ünal, S., Candan, F. B. and Yıldırım, H. (2012). The effect of brand satisfaction, trust and brand commitment on loyalty and repurchase intentions. Procedia-Social and Behavioral Sciences. vol. 58.

Fatema, M., Azad, M. A. K. and Masum, A. K. M. (2015). Impact of brand image and brand loyalty in measuring brand equity of islami bank Bangladesh Itd. Asian Business Review. vol. 2(1).

Grace, D. and O'Cass, A. (2005). Examining the effects of service brand communications on brand evaluation. Journal of Product\&Brand Management. vol. 14(2)

Harris, L. C., and Goode, M. M. (2004). The four levels of loyalty and the pivotal role of trust: a study of online service dynamics. Journal of retailing, vol. 80(2)

$\mathrm{He}, \mathrm{Y}$. and Lai, K. K. (2014). The effect of corporate social responsibility on brand loyalty: the mediating role of brand image. Total Quality Management \& Business Excellence. vol. 25(3/4)

Hoek, J., Dunnett, J., Wright, M. and Gendall, P. (2000). Descriptive and evaluative attributes: what relevance to marketers?. Journal of Product \& Brand Management. vol. 9(6).

Hohenstein, N, Sirgy, M. J., Herrmann, A. and Heitmann, M. (2007). Self-congruity: antecedents and consequences, Aix en Provance: France University Paul Cezanne.

Hoq, M. Z., Sultana, N., and Amin, M. (2010). The effect of trust, customer satisfaction and image on customers' loyalty in islamic banking sector. South asian journal of management, vol. 17(1).

Hsieh, Y. C. and Hiang, S. T. (2004). A study of the impacts of service quality on relationship quality in search-experience-credence services, Total Quality Management and Business Excellence. vol. 15(1).

Jones, T. O. and Sasser, W. E. (1995). Why satisfied customers defect. Harvard Business Review. vol. 73.

Kavaratzis, M. (2004). From city marketing to city branding: Towards a theoretical framework for developing city brands. Place Branding, vol. 1(1).

Keller, K.L. (1993). Conceptualizing, measuring, and managing customer-based brand equity. Journal of Marketing. vol. 57(1)

Kim, M. J., Chung, N., and Lee, C. K. (2011). The effect of perceived trust on electronic commerce: Shopping online for tourism products and services in South Korea. Tourism Management, vol. 32(2).

Laroche, M., Habibi, M. R. and Richard, M. O. (2013). To be or not to be in social media: How brand loyalty is affected by social media?. International Journal of Information Management. vol. 33(1).

Lee, D., Moon, J., Kim, Y. J. and Mun, Y. Y. (2015). Antecedents and consequences of mobile phone usability: Linking simplicity and interactivity to satisfaction, trust, and brand loyalty. Information \& Management. vol. 52(3)

Liao, Y. K. (2015). The Role of Trust on Brand Loyalty and Brand Equity. Joint International Conference.

Michaelidou, N., Micevski, M. and Cadogan, J.W (2015). An evaluation of nonprofit brand image: towards a better conceptualization and measurement. Journal of Business Research. vol. 68(8).

Momen, A., Haque, A., Omar, A., and Sultana, S. (2014). Exploring the brand image of an islamic higher educational institution: A qualitative approach. Middle East Journal of Business, vol. 9(2).

Morgan, R. M., and S. D. Hunt. (1994). The commitment-trust theory of relationship marketing. Journal of Marketing. vol. 58(3).

Nazari, E., Ghasemi, B., and Saeidi, S. S. (2015). Explain the relationship between green brand image, green satisfaction and green trust and factors affecting on green brand equity. Bulletin of The Georgian National Academy of Sciences. vol. 9(1)

Nikhashemi, S. R., Paim, L. H. and Khatibi, A. (2015). The role of brand loyalty in generating positive word of mouth among Malaysian hypermarket customers. World Academy of Science, Engineering and Technology, International Journal of Social, Behavioral, Educational, Economic and Management Engineering. vol. 9(5). 
Nikhashemi, S. R., Paim, L., Osman, S. and Sidin, S. (2015). The significant role of customer brand identification towards brand loyalty development: An empirical study among Malaysian hypermarkets customer. Procedia-Social and Behavioral Sciences. vol. 207.

Nyadzayo, M. W., and Khajehzadeh, S. (2016). The antecedents of customer loyalty: A moderated mediation model of customer relationship management quality and brand image. Journal of Retailing and Consumer Services. vol. 30

Orzan, G., Platon, O. E., Stefănescu, C. C. D. and Orzan, M. (2016). Conceptual model regarding the influence of social media marketing communication on brand trust, brand affect and brand loyalty. Economic Computation \& Economic Cybernetics Studies \& Research. vol. 50(1)

Rahi, S. (2015). Moderating Role of Brand Image With Relation to Internet Banking and Customer Loyalty: A Case for Branchless Banking. Journal of Internet Banking and Commerce. vol. 20(3)

Şahin, A., Zehir, C. and Kitapçı, H. (2012). Does brand communication increase brand trust? the ,empirical research of global mobile phone brands. Social and Behavioral Sciences. vol. 58.

Salinas, E. M. and Pérez, J. M. P. (2009). Modeling the brand extensions' influence on brand image. Journal of Business Research, vol. 62(1).

Kim, S. J., Choi, Y. K., Kim, K. H. and Liu, H. (2015). Country of origin and brand image influences on perceptions of online game quality. Journal of Consumer Behaviour. vol. 14(6)

Schivinski, B. and Dabrowski, D. (2015). the impact of brand communication on brand equity through facebook. Journal of Research in Interactive Marketing. vol. 9(1).

Šerić, M., Gil-Saura, I. and Ruiz-Molina, M. E. (2014). How can integrated marketing communications and advanced technology influence the creation of customer-based brand equity? Evidence from the hospitality industry. International Journal of Hospitality Management. vol. 39.

So, K. K. F., King, C., Sparks, B. A. and Wang, Y. (2014). The role of customer engagement in building consumer loyalty to tourism brands. Journal of Travel Research. vol. 55

Srivastava, N., Dash, S.B., and Mookerje, A. (2015). Antecedents and moderators of brand trust in the context of baby care toiletries. Journal of Consumer Marketing. vol. 32(5)

Veloutsou, C. (2015). Brand evaluation, satisfaction and trust as predictors of brand loyalty: the mediatormoderator effect of brand relationships. Journal of Consumer Marketing. vol. 32(6)

Virvilaite, R., Tumasonyte, D. and Sliburyte, L. (2015). The influence of word of mouth communication on brand equity: Receiver perspectives. Procedia-Social and Behavioral Sciences. vol. 213.

Wu, C.S. (2015). A study on consumers' attitude towards brand image, athletes' endorsement, and purchase intention. The International Journal of Organizational Innovation. vol. 8(2)

Xingyuan, W., Li, F. and Wei, Y. (2010). How do they really help? An empirical study of the role of different information sources in building brand trust. Journal of Global Marketing. vol. 23(3)

Zehir, C., Şahin, A., Kitapçı, H., and Özşahin, M. (2011). The effects of brand communication and service quality in building brand loyalty through brand trust; The empirical research on global brands. Procedia Social and Behavioral Sciences. vol. 24.

Zhang, K. Z., Benyoucef, M. and Zhao, S. J. (2016). Building brand loyalty in social commerce: The case of brand microblogs. Electronic Commerce Research and Applications. vol. 15. 